\title{
THE IMPORTANCE OF CD34 POSITIVE CELL QUANTIFICATION FOR HEMATOPOIETIC STEM CELL MOBILIZATION
}

\author{
Patricia Elkiki dos Santos ${ }^{1}$, Luiz Cláudio Ribeiro' ${ }^{1}$ Fernando Antônio Basile Colugnati' \\ Paula Alexandra da Graça Morais ${ }^{1}$, Rodrigo de Oliveira Andrade², Abrahão Elias Hallack Neto \\ 1 Universidade Federal de Juiz de Fora, Juiz de Fora, Minas Gerais, Brazil, 2 Hospital e Maternidade Monte Sinai, Juiz de Fora, \\ Minas Gerais, Brazil
}

Running title: IMPORTANCE OF CD34+ FOR HEMATOPOIETIC

Correspondence to: Patricia Elkiki dos Santos (patricia.elkiki@gmail.com)

\begin{abstract}
Objective: The success of autologus hematopoietic stem cell transplantation relies on CD34+ cells' availability in peripheral blood (PB), which is affected by several factors as age, sex, type of the disease, treatments, and others. In that regard, this prospective study aimed to evaluate the influence of these factors, correlating them with the pre-apheresis CD34+ cell count.
\end{abstract}

Method: Before autologous hematopoietic stem cell transplantation, CD34+ cells were quantified in the pre-apheresis PB and the final product. Then, after the determination of minimum CD34+ value, clinical and laboratory parameters were compared between patients with higher and lower CD34+ cells count.

\begin{abstract}
Results: Out of the 34 patients, 29 presented more than 20,000 leukocytes/ $\mu$ l. Patients who failed in the mobilization presented $<20,000$ leukocytes/ $\mu$ l. There was a significant difference between the groups with different pre-apheresis CD34+ cells status regarding age $(p=0.025)$, leukocyte count $(p<0.001)$ and mononuclear cells $(p=0.001)$ in PB. In addition, the pre-apheresis CD34+ $\geq 14$ cells/ $\mu$ l group was related to a better yield of these cells in the final product and with the requirement of a single collection to obtain the minimum yield, of $2 \times 106$ CD34+/kg.
\end{abstract}

Conclusion: This study demonstrates age and leukocyte count relate to CD34+ count in PB, and that CD34+ cells yield in the collection, can be predicted by CD34+ cells frequency in PB.

Keywords: Stem Cells. CD34 positive cells. Autologous Hematopoietic stem cell transplantation. flow cytometry.

\section{INTRODUCTION}

Peripheral blood stem cell transplantation is highly indicated as a therapeutic strategy for patients who have undergone high doses of chemotherapy for malignant hematological or solid neoplasms. Furthermore, the success of stem cell transplantation and grafting depends on the infusion of an adequate number of progenitor cells ${ }^{1-3}$.

Hematopoietic stem cells (HSC) have the capacity for self-renewal and present proliferative potential, allowing them to differentiate into progenitor cells of all blood lineages and the reconstitute the hematopoietic population ${ }^{4-5}$. These cells express CD34 on their cytoplasmatic membrane, which can be used as a marker to assess this population ${ }^{5}$.

In unstimulated healthy donors, HSC constitutes 0.01 to $0.1 \%$ of peripheral blood cells (PB) and 1 to $3 \%$ of all bone marrow (BM) cells ${ }^{6}$. However, for autologous transplantation of hematopoietic progenitor cells (AHSCT), it is recommended a minimum dose of $2 \times 106 \mathrm{CD} 34+$ cells $/ \mathrm{kg}^{7}$, making it necessary 
to mobilize those cells from the BM. In that sense, the most commonly used forms of HSC mobilization from $B M$ to $P B$ is the isolated use of growth factors, or their combination with chemotherapeutic agents. Among the available growth factors, the most commonly used is the recombinant granulocyte colony-stimulating factor (G-CSF) ${ }^{8-9}$. Another approach is the use of plerixafor, which inhibits CXCR4 present in CD34 + cells, associated with G-CSF ${ }^{10}$.

Several factors have been reported to affect HSC mobilization, such as age, sex, type of disease, bone marrow conditions, prior chemotherapy and radiotherapy, and stability of peripheral blood CD34 + cell counts ${ }^{11-14}$. Hence, the present study aimed to evaluate the influence of the above-mentioned factors on HSC mobilization, in patients treated with G-CSF before AHSCT.

\section{Material and Methods}

A prospective, non-probabilistic evaluation was performed on 34 patients undergoing HSC mobilization in the Bone Marrow Transplantation services of the University Hospital (UFJF) and the Monte Sinai Hospital and Maternity, from February 2016 to July 2017. This study was approved by the Ethics Committee on Research in Human Beings of HU-UFJF (CEP HUUFJF), embodied report no. 1,419,207 and CAAE 53105615.9.0000.5133.

\section{Patients}

Patients undergoing HSC mobilization with G-CSF were included irrespective of gender, age, or underlying diseases. All patients, who accepted to participate in the study, signed the informed consent form (ICF). Patients subjected to G-CSF mobilization protocol while in chemotherapy, or who did not have the clinical criteria to perform the AHSCT were excluded.

\section{CD34+ cells quantification}

The CD34+ count was performed on the fourth mobilization day, however, the CD34+ value of the first day of collection was included for data analysis. The collection started when the CD34 + cell count was $\geq 10$ cells $\mu \mathrm{L}$ in the PB. Nevertheless, when patients did not reach this value, after 5 days of G-CSF treatment, it was considered a mobilization failure. Quantification of CD34+ cells was performed on a double platform. The cytometry was carried out on the flow cytometer Fluorescence-Activated Cell Analyzer, FACSCalibur, Becton Dickinson (BD), and its analysis performed on the Cell Quest analysis software ac- cording to the International Society of Hematology and Graft Engineering ISHAGEprotocol ${ }^{15}$, and the hemogram was obtained in the Mindray hematological counter (BC-2800).

For CD34+ cells quantification, the following antibodies were used: CD45 monoclonal antibody conjugated with fluorescein (FITC), monoclonal antibody CD34 conjugated with phycoerythrin (PE), monoclonal antibody isotype IgG1-PE (negative control). $2 \times$ 106 cells were platted in an adjusted volume of $50 \mu \mathrm{l}$ to $100 \mu \mathrm{l}$. Two tubes were identified, one as "control" and another as "patient", in each 10 $\mu \mathrm{l}$ of anti-CD45 antibody were added; in the control tube $10 \mu$ of anti-IgG1 were added, and in the patient tube $10 \mu \mathrm{l}$ of anti-CD34 were added. The tubes were homogenized in vortex and incubated for 20 minutes at room temperature, protected from light. After the incubation time, $2 \mathrm{ml}$ of lysing solution were added, followed by homogenization and 10 minutes incubation, at room temperature, protected from light. After the incubation period, the cytometer analysis was performed.

\section{Data analysis}

The collected data were gathered for descriptive and inferential analysis, frequency, median, minimum and maximum distributions, average, and standard deviation, presented in tables.

After determining the minimum value of CD34+ cells in the PB, for a sensitivity of $100 \%$ by the Receiver Operating Characteristic(ROC) curve (Figure 1), related to the lower number of collections to obtain the minimum value for AHSCT (14 CD34 + cells/ $\mu$ in PB), two groups were created. Patients with CD34+ cells counting $<14$ cells/ $\mu$ land patients with CD34 + cells $\geq 14$ cells/ $\mu$ l were compared regarding the averages of age, global leukocytes count, mononuclear cells, platelet count, as well as the yield of CD34 + cells in the final product, statistical significance was checked through unpaired Student's t test. However, a previous assessment of normality was performed through the Shapiro-Wilk test and the Levene variance homogeneity test.

The chi-square test was used in order to associate categorical variables (CD34+ cells and sex, number of collections, disease, radiotherapy, chemotherapy cycles, disease status during mobilization, protocol number and BM infiltration). The test was chosen according to the assumptions of any box in the table of expected values smaller than 1 and greater than or equal to 5 , in at least $80 \%$ of the samples. The association with myelotoxic drugs was not tested, as only 
one patient was using such medication. Additionally, it was also not possible to test the infiltration of BM, since none of the patients with lymphoma presented BM involvement.

The analyzes were performed in the software Statistical Package for Social Science ${ }^{\circledast}$ (SPSS) version 17.0. For the statistically significant values, the $p$ value $\leq 0.05$ was considered for rejection of the null hypothesis.

\section{Results}

From 34 evaluated patients, only 2 non-Hodgkin lymphoma patients, aged 38 and 47, have failed mobilization. The characteristics of the 34 patients, among which 32 managed to reach a minimum of $2 \times 106$, are shown in Table 1. The average dose of G-CSF was $11.4 \mu \mathrm{g} / \mathrm{kg} /$ day.

Among the tested variables (sex, disease, disease status, whether the patient was in complete remission or not, platelet count, previous radiotherapy, previous chemotherapy protocols, whether the patient had one or more protocols, number of cycles, mobilization, amount of G-CSF / kg/day) there was no significant difference between the proposed groups based on CD34 + cells population. However, the $\geq 14$ cells/ $\mu$ lvalue was associated withthe need for a single collection to reach the aim of $2 \times 10^{6} \mathrm{CD} 34+/ \mathrm{kg}$, for the AHSCT.

Twenty-nine (85\%) patients presented more than 20,000 leukocytes/ $\mu \mathrm{l}$, among which $95 \%$ had CD34+ cells count $\geq 14$, while only $4,2 \%$ of them displayed lower values. Moreover, the two patients who failed in the mobilization presented less than 20,000 leukocytes / $\mu$ l. In addition, patients with CD34+ $\geq 14$ cells / $\mu$ l were younger, presenting a difference in the average of leukocytes and pre-leukapheresis mononuclear cells. (Table 2).

Except for the patients who failed in the mobilization, the CD34 $+\geq 14$ cells / $\mu$ l was related to the need for only one collection and a better yield in the final product (Table 3 ), with a significant difference $(p=0.002)$ between those which required one collection, compared to the those who needed two or more. FurthermoreThe number of CD34 + cells in the final product of apheresis collections was higher in patients presenting CD34 $+\geq 14$ cells $/ \mu \mathrm{L}$ in $\mathrm{PB}$, when compared to those with $\mathrm{CD} 34+<14$ cells $/ \mu \mathrm{l}$, respectively $4.98 \times 106$ and $2.87 \times 106 \mathrm{CD} 34+/ \mathrm{kg}(\mathrm{p}=$ 0.002). (Table 4)

\section{Discussion}

Among the 34 patients, only 2 (5.88\%) patients failed in the mobilization, while no MM patient failed it. This finding is consistent with others describing the failure of 5 to $40 \%$ of patients ${ }^{7,16}$. Although, underlying diseases were not related to mobilization failure, it is noteworthy that the two failing patients had $\mathrm{NHL}$. On that way, the percentage of failures within this diagnosis were similar to another Brazilian center ${ }^{17}$. According to Stiff et al ${ }^{18}$, prior chemotherapy and radiotherapy impair HSC mobilization, however, in our study, those factors did not affect the number of CD34+ cells in post-mobilization PB.

Consistent with the literature, younger patients demonstrated higher mobilization capacity, with the average ages of 55 and. 45 years, for the patients with $\mathrm{CD} 34+<14$ cells $/ \mu \mathrm{l}$ and $\geq 14$ cells $/ \mu$ l respectively. As described, it may indicate that older people would be more likely to present mobilization failure than younger people, this probably relates to the lower marrow reserve, in the older group ${ }^{17,19}$. Although young patients have been correlated with a higher number of CD34+ cells, guide mobilization, based only on clinical datamay lead to an overtreatment of patients who may be good mobilizers, as well as to undertreatment of those who fail in the mobilization.

The average global leukocyte count among individuals with CD34+cell $\geq 14$ cells/ $\mu$ l was higher than in those with a $<14$ cells/ $\mu$ l count, showing an association between global leukocyte and CD34+cells counts $(p<0.001)$. In that regard, studies show there is little correlation between leukocytes count in PB and the number of CD34+ cells in PB, and our findings allow us to conjecture that the initial dosage of CD34 associated with less than 20,000 leukocytes/ $\mathrm{mm} 3$ would be unproductive, and would end up making the process more expensive ${ }^{3,20}$.

Among the leukocytes, the PB mononuclear population was higher in the CD34+ cell $s \geq 14$ cells $/ \mu \mathrm{l}$ group ( $p=0.001)$. However, there are no reports of this correlation, and it can be important to guide a pre-selection of patients to undergo CD34 count, optimizing the mobilization process ${ }^{21}$.

According to the consensus of the American Society for Blood and Marrow Transplantation (ASBMT), the minimum cell value for performing AHSCT is $2 \times 10^{6}$ CD34 + cells $/ \mathrm{kg}$, however the decision to perform the AHSCT between $1 \times 0^{6}$ and $2 \times 10^{6}$ CD34 + cells/ 
$\mathrm{kg}$ can be taken according to the patient, still there is aim for3x106 [10]. In that way, higher CD34+ yield in the final apheresis product associatiated with CD34+ $\geq 14$ cells $/ \mu \mathrm{L}$ cells in peripheral blood $(p=0.002)$, demonstrating the importance of the CD34+ cells count during mobilization for a suitable final product, as demonstrated in other studies ${ }^{13,16,22}$.

Sixty-seven percent of patients with $\mathrm{CD} 34+\geq 14$ cells/ $\mu \mathrm{L}$ in $\mathrm{PB}$ achieved the minimum counts required for AHSCT with a single collection, while all patients with less than 14 CD34 + cells/ $\mu \mathrm{L}$ cells performed two or more collections. This data reinforces the importance of CD34+ cells count on mobilization, as a success predictor in the collection of hematopoietic stem cells from peripheral blood (HSCPB).

Based on our findings and the literature, the use of CD34+ cells counts to guide interventions, to avoid mobilization failures and improve the yield of the final product, should be encouraged. Nevertheless the two patients who failed mobilization were subjected to one collection which enabled the AHSCT, after a second mobilization with cyclophosphamide and G-CSF, however $t$ the use of chemotherapy increases

\section{REFERENCES}

1. Siena S, Schiavo R, Pedrazzoli P, Carlo-Stella C. Therapeutic relevance of CD34+ cell dose in blood stem cell transplantation for cancer therapy. J ClinOncol 2000;18(6):1360-77.

2. Jantunen E, Kuittinen T. Blood stem cell mobilization and collection in patients with lymphoproliferative diseases: practical issues. Eur J Haematol 2008;80(4):287-95.

3. Peerschke El, Moung C, Pessin MS, Maslak P. Evaluation of new automated hematopoietic progenitor cell analysis in the clinical management of peripheral blood stem cell collections. Transfusion. 2015;55(8):2001-9.

4. Devetten M, Armitage JO. Hematopoietic cell transplantation: progress and obstacles. Ann Oncol. 2007;18(9):1450-6.

5. Vigorito AC, Souza CA. Hematopoietic stem cell transplant and recovery of hematopoiesis. Rev Bras Hematol Hemoter. 2009;31(4):280-4.

6. Golubeva V, Mikhalevich J, Novikova J, Tupizina O, Trofimova S, Zueva Y. Novel cell population the infectious risks and leads to new costs. Anyway, that the measure of CD34 + cells on the fourth day, can be used to optimize the mobilization ${ }^{9,23}$.

Although the rate of mobilization failureis compatible with the literature, early intervention based on CD34 + cells may be able to reverse the results on patients who could not reach the minimum number of cells for leukapheresis.

\section{Conclusion}

We conclude that the CD34+ cell count in the peripheral blood is related to age and number of leukocytes, being the only factor with a significant association with the number of collections and the yield of the final product.

\section{Acknowledgements}

We would like to thank the whole transplantation team from the Centro de Transplante de Medula Óssea from the Monte Sinai Hospital and Maternity (Juiz de Fora - MG - Brazil), mainly Dr. Angelo Atalla.

data from a haematology analyzer can predict timing and efficiency of stem cell transplantation. Transfus Apher Sci. 2014;50(1):39-45.

7. Giralt S, Costa L, Schriber J, Dipersio J, Maziarz $\mathrm{R}$, McCarty J, et al. Optimizing autologous stem cell mobilization strategies to improve patient outcomes: consensus guidelines and recommendations. Biol Blood Marrow Transplant. 2014;20(3):295-308.

8. Sheppard D, Bredeson C, Allan D, Tay J. Systematic review of randomized controlled trials of hematopoietic stem cell mobilization strategies for autologous transplantation for hematologic malignancies. Biol Blood Marrow Transplant. 2012;18(8):1191-203.

9. Salvino MA, Ruiz J. Hematopoietic progenitor cell mobilization for autologous transplantation - a literature review. Rev Bras Hematol Hemoter. 2016;38(1):28-36.

10. Costa LJ, Nista EJ, Buadi FK, Lacy MQ, Dispenzieri A, Kramer CP, Edwards KH, et al. Prediction of Poor Mobilization of Autologous CD34+ Cells 
with Growth Factor in Multiple Myeloma Patients: Implications for Risk-Stratification. Biol Blood Marrow Transplant. 2014;20(2):222-8.

11. Sarkodee-Adoo C, Taran I, Guo C, Buadi F, Murthy R, Cox E, et al. Influence of preapheresis clinical factors on the efficiency of CD34+ cell collection by large-volumen apheresis. Bone Marrow Transplant. 2003;31(10):851-5.

12. Desikan KR, Tricot G, Munshi NC, Anaissie E, Spoon D, Fassas A, et al. Preceding chemotheraphy, tumor load and age influence engraftment in multiple myeloma patients mobilized with granulocyte colony-stimulating factor alone. $\mathrm{Br}$ J Haematol. 2001;112(1):242-7.

13. Ford CD, Chan KJ, Reilly WF, Petersen FB. An evaluation of predictive factors for CD34+ cell harvest yields from patients mobilized with chemotherapy and growth factors. Transfusion. 2003;43(5):622-5.

14. Anguita-Compagnon AT, Dibarrart MT, Palma L, Paredes L, Mosso C, Montalva R, et al.. Mobilization and Collection of Peripheral Blood Stem Cells: Guidelines for Blood Volume to Process, Based on CD34-Positive Blood Cell Count in Adults and Children. Transplantation Proceedings. 2010;42(1):339-44.

15. Sutherland DR, Anderson L, Keeney M, Nayar R, Chin-Yee I. The ISHAGE guidelines for CD34+ cell determination by flow cytometry. International Society of Hematotherapy and Graft Engineering. J Hematother. 1996;5(3):213-26.

16. Sakashita AM, Kondo AT, Ribeiro AA, Cipolleta AN, Colesanti MV, Hamerschlak N, et al. Factors affecting autologous peripheral blood hematopoietic stem cell collections by large-volume leukapheresis: a single center experience. Einstein (São Paulo). 2011;9(2):196-200.
17. Mendrone A Jr., Arrais CA, Saboya R, Chamone DA, Duley FL. Factors affecting hematopoietic progenitor cell mobilization: An analysis of 307 patients. Transfus Apher Sci. 2008;39(3):187-92.

18. Stiff P, Gingrich R, Luger S, Wyres MR, Brown RA, LeMaistre $C F$, et al. A randomized phase 2 study of PBPC mobilization by stem cell factor and filgrastim in heavily pretreated patients with Hodgkin's disease or non-Hodgkin's lymphoma. Bone Marrow Transplant. 2000;26(5):471-81.

19. Özkurt ZN, Yegin ZA, Suyani E, Aki SZ, Acar K, Yagci $M$, et al. Factors affecting stem cell mobilization for autologous hematopoietic stem cell transplantation. J ClinApher. 2010;25(5):280-6.

20. Yu J, Leisenring W, Bensinger WI, Holmberg LA, Rowley SD. The predictive value of white cell or CD34+ cell count in peripheral blood for timing of apheresis and maximizing yield. Transfusion 1999;39(5):442-50.

21. Sakashita AM, Kondo AT, Yokoyama AP, Lira SM, Bub CB, Souza AM, et al. The impact of preapheresis white blood cell count on autologous peripheral blood stem cell collection efficiency and HSC infusion side effect rate. J Clin Apher. 2018;33(3):331-41.

22. Basquiera $A L$, Abichain $P$, Damonte $J C$, Ricchi $B$, Sturich AG, Palazzo ED, et al. The number of CD34(+) cells in peripheral blood as a predictor of the CD34(+) yield in patients going to autologous stem cell transplantation. J Clin Apher 2006;21(2):92-5.

23. Costa LJ, Alexander ET, Hogan KR, Schaub C, Fouts TV, Stuart RK. Development and validation of a decision-making algorithm to guide the use of plerixafor for autologous hematopoietic stem cell mobilization. Bone Marrow Transplantation. 2011;46(1):64-9. 
TABLE 1 - Socio-demographic, clinical and laboratory data of patients subject to G-CSF mobilization protocol, in order to achieve optimum CD34+ countings in PB.

\begin{tabular}{|c|c|c|}
\hline VARIABLES & $\begin{array}{l}\text { TOTAL } \\
\mathbf{N}=34\end{array}$ & $\begin{array}{c}\text { MOBILIZED } \\
\mathrm{N}=32\end{array}$ \\
\hline Age & \multirow{2}{*}{$49,5(14-69)$} & \multirow{2}{*}{$52,5(14-69)$} \\
\hline Average & & \\
\hline \multicolumn{3}{|l|}{ Sex } \\
\hline Male & $18(52,9 \%)$ & $18(56,3 \%)$ \\
\hline Female & $16(47,15 \%)$ & $14(43,7 \%)$ \\
\hline \multicolumn{3}{|l|}{ Transplant Center } \\
\hline University Hospital - UFJF & $22(64,7 \%)$ & $20(62,5 \%)$ \\
\hline Monte Sinal Hospital & $12(35,3 \%)$ & $12(37,5 \%)$ \\
\hline \multicolumn{3}{|l|}{ Disease } \\
\hline MultipleMyeloma & $23(67,6 \%)$ & $23(71,9 \%)$ \\
\hline Lymphomas & $11(32,4 \%)$ & $9(28,1 \%)$ \\
\hline \multicolumn{3}{|l|}{ Disease Status in Mobilization } \\
\hline Complete remission & $15(44,1 \%)$ & $14(43,8 \%)$ \\
\hline Without complete remission & $19(55,9 \%)$ & $18(56,2 \%)$ \\
\hline \multicolumn{3}{|l|}{ Number of prior chemotherapy regimens } \\
\hline 1 & $25(73,5 \%)$ & $25(78,1 \%)$ \\
\hline$\geq 2$ & $9(26,5 \%)$ & $7(21,9 \%)$ \\
\hline Number of Cycles & \multirow{2}{*}{$6(3-15)$} & \multirow{2}{*}{$5(3-15)$} \\
\hline Average & & \\
\hline \multicolumn{3}{|l|}{ Radiotherapy } \\
\hline Yes & $12(35,3 \%)$ & $11(34,4 \%)$ \\
\hline No & $22(64,7 \%)$ & $21(65,6 \%)$ \\
\hline G-CSF/Kg/day & \multirow{2}{*}{$11,3(10-19,6)$} & \multirow{2}{*}{$11,3(10-14)$} \\
\hline Average & & \\
\hline Interval between start of mob. CD34+ peak (days) & \multirow{2}{*}{$4(3-6)$} & \multirow{2}{*}{$4(3-6)$} \\
\hline Average & & \\
\hline \multicolumn{3}{|l|}{ Apheresis number } \\
\hline 1 collection & $16(50 \%)$ & $16(50 \%)$ \\
\hline$\geq 2$ collections & $16(50 \%)$ & $16(50 \%)$ \\
\hline $\mathrm{N}^{\circ}$ of leukocytes in PB pre-leukoapheresis $(\mu \mathrm{L})$ & \multirow{2}{*}{$30.750(4.900-70.600)$} & \multirow{2}{*}{$32.600(5.300-70.600)$} \\
\hline Average & & \\
\hline No CD34+ cells in PB pre-leukoapheresis $(\mu \mathrm{L})$ & \multirow{2}{*}{$22(2-98)$} & \multirow{2}{*}{$22,5(9-98)$} \\
\hline Average & & \\
\hline$N^{\circ}$ of mononuclear cells in PB pre-leukoapheresis $(\mu \mathrm{L})$ & \multirow{2}{*}{$3.900(1300-16.600)$} & \multirow{2}{*}{$4.200(1.700-16.600)$} \\
\hline Average & & \\
\hline $\mathrm{N}^{\circ}$ of platelets in PB pre-leukoapheresis $(\mu \mathrm{L})$ & \multirow{2}{*}{$182.000(29.000-335.000)$} & \multirow{2}{*}{$\begin{array}{c}182.000(29.000- \\
335.000)\end{array}$} \\
\hline Average & & \\
\hline $\mathrm{N}^{\circ}$ of $\mathrm{CD} 34+$ in final product & \multirow{2}{*}{$4,07(1,51-12,41)$} & \multirow{2}{*}{$4,07(1,51-12,41)$} \\
\hline Average & & \\
\hline
\end{tabular}


TABLE2 - Comparison between the designated groups according to their amount of CD34+ cells in $\mathrm{PB}(<14$ cells $/ \mu \mathrm{l}$ and $\geq 14$ cells $/ \mu \mathrm{l})$, regarding the factors which can influence the quantity of recovered cells.

\begin{tabular}{|c|c|c|c|c|c|}
\hline Variable & $\begin{array}{l}\text { CD34 in peripherial } \\
\text { blood }\end{array}$ & $\mathbf{N}$ & Average & Standard deviation & p-value \\
\hline \multirow{2}{*}{ Age } & $<14$ cells $/ \mu \mathrm{l}$ & 10 & 55,3 & 9,0 & $0,025^{*}$ \\
\hline & $\geq 14$ cells $/ \mu \mathrm{l}$ & 24 & 45,2 & 15,7 & \\
\hline \multirow{2}{*}{ Global LeucocyteCount } & $<14$ cells $/ \mu$ l & 10 & 17860,0 & 7486,6 & $<0,001^{*}$ \\
\hline & $\geq 14$ cells $/ \mu \mathrm{l}$ & 24 & 38033,3 & 13807,2 & \\
\hline \multirow{2}{*}{ Mononuclear cells } & $<14$ cells $/ \mu \mathrm{l}$ & 10 & 2922 & 1032,64 & $0,001^{*}$ \\
\hline & $\geq 14$ cells $/ \mu \mathrm{l}$ & 23 & 5898 & 3730,05 & \\
\hline
\end{tabular}

*p-value obtained via T Student's Test.

TABLE3 - Comparison between the designated groups according to their amount of CD34+ cells in $\mathrm{PB}(<14$ cells $/ \mu \mathrm{l}$ and $\geq 14$ cells $/ \mu \mathrm{l})$ and association with the number of apheresis required to achieve optimal CD34+ cells counting.

\begin{tabular}{|c|c|c|c|c|c|c|}
\hline & \multirow{2}{*}{\multicolumn{2}{|c|}{$\begin{array}{l}<14 \text { cells } / \mu l \\
\geq 14 \text { cells } / \mu l\end{array}$}} & \multicolumn{2}{|c|}{ CD34 } & \multirow[b]{2}{*}{ Total } & \multirow[b]{2}{*}{${ }^{*} p$ value } \\
\hline & & & & & & \\
\hline \multirow{4}{*}{$\begin{array}{l}\text { Number of collections } \\
\text { performed }\end{array}$} & \multirow{2}{*}{1 apheresis } & Counting & 0 & 16 & 16 & \multirow{4}{*}{0,002} \\
\hline & & $\%$ inside CD34 & $0,0 \%$ & $100,0 \%$ & $100,0 \%$ & \\
\hline & \multirow{2}{*}{$\geq 2$ apheresis } & Counting & 8 & 8 & 16 & \\
\hline & & $\%$ inside CD34 & $50,0 \%$ & $50,0 \%$ & $100,0 \%$ & \\
\hline
\end{tabular}

*p-value obtained via Chi-Square test

TABLE 4 - Association between the amount of CD34+ cells in PB and the quantity of these cells recovered in the FP.

\begin{tabular}{c|c|c|c|c|c}
\hline & $\mathrm{CD} 34$ & $\mathrm{~N}$ & $\begin{array}{c}\text { Average } \\
(\mathrm{CD} 34 \times 106 / \mathrm{Kg})\end{array}$ & $\begin{array}{c}\text { Standard } \\
\text { deviation }\end{array}$ & *p value \\
\hline \multirow{2}{*}{ CD34 Final Product } & $<14 \mathrm{CD} 34+/ \mu \mathrm{L}$ & 8 & 2,87 & 1,03 & 0,002 \\
\cline { 2 - 5 } & $\geq 14 \mathrm{CD} 34+/ \mu \mathrm{L}$ & 24 & 4,98 & 2,41 \\
\hline
\end{tabular}

*p-value obtained via T Student's test 